\title{
KOLABORASI QUADRUPLE HELIX DALAM MENCIPTAKAN INOVASI KONSEP WISATA EDUKASI KAMPUNG NANAS DI DESA PALAAN
}

\author{
Muhamad Imron \\ Program Studi Ilmu Pemerintahan, Fakultas Ekonomi dan Ilmu Sosial, Universitas Islam Raden Rahmat Malang \\ Imron.unira@gmail.com
}

\begin{abstract}
Abstraksi
Menciptakan konsep desa wisata bukanlah perkara yang mudah karena memerlukan kerjasama banyak pihak. Kolaborasi antar sektor (pemerintah, akademisi, bisnis, masyarakat) menjadi kunci dalam menggerakkan kreatifitas dan inovasi agar produk yang dihasilkan menjadi unggul dan berdaya saing ditengah industri wisata yang semakin beragam. Kolaborasi yang ideal menghasilkan interaksi yang setara dan saling berbagi pengetahuan. Penelitian ini menggunakan pendekatan kualitatif dengan metode penelitian deskriptif. Metode ini diharapkan dapat menghasilkan uraian secara jelas dan mendalam perihal ucapan, perilaku dan tulisan yang dapat diamati dari individu, kelompok masyarakat ataupun organisasi tertentu. Penelitian ini menjelaskan bentuk kerjasama kolaboratif antar elemen Quadruple Helix di desa Palaan. Model empat helix ini dinilai efektif karena memberi ruang yang seimbang kepada seluruh stakeholder yang ada, terutama masyarakat yang seringkali hanya diposisikan sebagai obyek suatu kebijakan. Melalui model ini, selain menciptakan inovasi konsep wisata edukasi, diharapkan juga dapat memaksimalkan potensi desa yang berdampak pada kesejahteraan dan kemandirian desa.
\end{abstract}

Kata Kunci: Quadruple Helix, kolaborasi, inovasi, kreatifitas

\begin{abstract}
Creating the concept of a tourist village is not an easy matter because it requires the cooperation of many parties. Collaboration between sectors (government, academia, business, community) is the key in driving creativity and innovation so that the products produced become superior and competitive amid an increasingly diverse tourism industry. Ideal collaboration results in equal interaction and knowledge sharing. This research uses a qualitative approach with descriptive research methods. This method is expected to produce a clear and in-depth description of speech, behavior and writing that can be observed from individuals, community groups or certain organizations. This study describes the form of collaborative collaboration between Quadruple Helix elements in the village of Palaan. The four-helix model is considered effective because it gives a balanced space to all existing stakeholders, especially the community which is often only positioned as an object of a policy. Through this model, in addition to creating innovative educational tourism concepts, it is also expected to maximize the potential of villages that have an impact on the welfare and independence of the village.
\end{abstract}

Keywords: Quadruple Helix, collaboration, innovation, creativity

\section{PENDAHULUAN}

Kesadaran desa untuk berlomba mengembangkan inovasi semakin tidak bisa ditawar lagi. Bagi desa yang telah berhasil berinovasi dengan segala potensi yang di miliki tentu bakal menerima panin dikemudian hari. Pendapatan asli desa akan meningkat, tingkat kesejahteraan masyarakat semakin membaik, angka pengangguran berkurang signifikan serta termanfaatkannya sumberdaya manusia dan sumber daya alam yang dimiliki oleh desa adalah sekian rentetan yang dapat diterima saat sebuah desa telah berhasil mengembangkan inovasi. Inovasi memang tidak selalu berkaitan erat dengan (ide) hal yang sama sekali baru, ia bisa saja merupakan hasil replikasi dari tempat lain, namun saat ide tersebut diambil, kemudian melalui serangkaian proses perubahan dan penyesuaian dengan lingkungan baru dan berujung pada dimunculkannya sisi baru yang dilekatkan yang tidak ada pada tempat asal replikasi tersebut. Sebelum suatu inovasi muncul, idealnya terdapat serangkaian proses yang harus dilalui oleh desa, seperti pemetaan potensi desa, focus group discuss, menggelar workshop hingga memanfaatkan jejaring yang berpotensi membantu dalam mencapai tujuan. Bagi banyak desa, ini adalah pekerjaan berat. Ketersediaan sumberdaya manusia yang minim seringkali menjadi alasan untuk sekedar memulai menggapai harapan tersebut. Dan kolaborasi merupakan suatu keniscayaan yang dapat dilakukan oleh desa agar tujuan besarnya bisa dengan cepat tercapai.

Hingga tahun 2018, situs resmi Kementerian Desa, Pembangunan Daerah Tertinggal dan Transmigrasi merilis jumlah desa yang telah melakukan berbagai macam inovasi sesuai karakter daerahnya masing-masing sebanyak 30.000 desa. Saat ini, kementerian desa memang memberikan perhatian lebih pada narasi besar yang telah dibangun yakni one village, one innovation. Angka 30.000 desa yang telah berhasil menyajikan inovasi diatas terdiri dari inovasi pada bidang wirausaha desa, wisata desa, produk unggulan desa, pemerintahan yang baik, hingga teknologi tepat guna. 
Artikel ini menyajikan praktik kolaborasi yang terbangun antar berbagai stakeholder dalam mensukseskan program PIID-PEL (Pilot Inkubasi Inovasi Desa Pengembangan Ekonomi Lokal) pada desa Palaan kecamatan Ngajum kabupaten Malang. Perlu diketahui, desa Palaan memiliki embrio produk unggulan kawasan perdesaan berupa buah nanas. Hal paling dianggap unik dari jenis nanas yang ditanam di desa tersebut yaitu ukurannya yang besar hingga mencapai lebih dari $5 \mathrm{Kg}$ serta daunnya yang panjang dan tidak memiliki duri. Harga jual nanas ini bisa mencapai Rp. 15.000,- untuk setiap kilogramnya. Sebelum program inovasi ini bergulir, kebanyakan warga desa Palaan menanam buah nanas hanya disekitar pekarangan rumah ataupun lahan kosong saja. Permasalahan pertama yang muncul adalah saat buah nanas tersebut belum masuk masa panin yang berarti tidak ada yang dapat dijual oleh warga sekitar. Masa panin buah nanas dapat mencapai 6 hingga 7 bulan.Permasalahan kedua yang dirasakan oleh warga berupa tidak mencukupinya hasil penjualan buah nanas untuk mencukupi kebutuhan sehari-hari.

Butuh inovasi konsep dan kolaborasi untuk merubah persoalan yang ada menjadi peluang yang dapat ditangkap oleh warga desa Palaan. Inovasi seringkali muncul terutama paska kolaborasi antar stakeholder dilakukan. Saling tukar ide dan gagasan serta pengalaman antar aktor dapat menggiring suatu terobosan yang mungkin sebelumnya belum pernah terpikirkan. Kolaborasi pada program PIID-PEL diatas melibatkan empat aktor yakni pemerintah, masyarakat, pelaku usaha kreatif dan perguruan tinggi. Kolaborasi empat aktor tersebut selanjutnya disebut dengan Quadruple Helix, suatu model yang lazim digunakan untuk melahirkan inovasi pada sektor ekonomi termasuk di dalamnya membangun desa wisata. Sakinah dan Sofhani (2016) menyebutkan bahwa model Quadruple Helix ini merupakan strategi baru dalam upaya pengembangan di wilayah pedesaan di Indonesia. Demikian pula Widjajani, fajarwati dan Hidayat (2016) juga mengemukakan bahwa model Quadruple Helix dengan konsep customized dapat disesuaikan dengan situasi dan kondisi sumber daya yang ada pada tiap daerah sehingga dapat digunakan sebagai model dalam pengembangan inovasi daerah.

\section{METODE}

Penelitian ini menggunakan pendekatan kualitatif dengan metode penelitian deskriptif. Metode ini diharapkan dapat menghasilkan uraian secara jelas dan mendalam perihal ucapan, perilaku dan tulisan yang dapat diamati dari individu, kelompok masyarakat ataupun organisasi tertentu. Peneliti menggunakan instrumen berupa wawancara mendalam dan observasi lapangan guna memperoleh data. Selanjutnya data yang telah diperoleh dianalisis dengan cara non statistik sebagaimana sifat metode penelitian deskriptif dimana seorang peneliti akan membuat deskripsi secara sistematis, faktual serta akurat terkait fakta dari lokasi penelitian di desa Palaan, kecamatan Ngajum, kabupaten Malang.

\section{HASIL DAN PEMBAHASAN}

\section{Potensi dan peluang yang dimilikiDesa Palaan}

Desa Palaan terletak pada posisi $8^{\circ} 11^{\prime}-2^{\circ} 24^{\prime}$ Lintang Selatan dan $112^{\circ} 54^{\prime}-70^{\circ} 53$ Bujur Timur. Secara administratif desa ini berada di kecamatan Ngajum kabupaten Malang provinsi Jawa Timur. Adapun total lahan desa Palaan adalah 246, $10 \mathrm{Ha}$. Luas sawah sebesar 105,10 Ha. Sedangkan lahan kering seluas 141,00 Ha yang terdiri dari 1). Lahan permukiman/pekarangan adalah 123,60 Ha, 2). Kebun seluas 8,60 Ha. Lahan lainnya adalah 8,60 Ha. (BPS: 2018). Desa Palaan terbagi menjadi 10 Rukun Warga (RW) yang tergabung di dalam2 Dusun yakni Palaan-Krajan dan Sukoyuwono yang masing-masing dipimpin oleh Kepala Dusun. Berdasarkan data administrasi desa tahun 2014, jumlah penduduk desa Palaan adalah 3.406 jiwa dengan rincian 1.699 laki-laki dan 1.707 perempuan. Jumlah kepala keluarga $938 \mathrm{KK}$.

Desa Palaan dikenal memiliki produk unggulan desa berupa buah nanas dengan spesifikasi agak unik yakni postur buah yang terbilang cukup besar hingga mencapai lebih dari $5 \mathrm{Kg}$, daun yang panjang hingga 30 $\mathrm{cm}$ dan tidak berduri. Kebanyakan, buah nanas tersebut ditanam di pekarangan dan kebun warga. Potensi lain yang dimiliki oleh desa Palaan ialah akses strategis yang terhubung dengan kawasan wisata religi Gunung Kawi yang telah cukup tersohor, berada pada gerbang kecamatan Ngajum, serta letak lokasi yang berada di akhir akses Jalur Lingkar Barat (Jalibar).

Warga desa Palaan telah mengembangkan pemanfaatan lahan pekarangan rumah untuk ditanami buah nanas. Selain untuk menambah estetika halaman rumah, melalui penanaman buah nanas juga dapat menambah pendapatan dan mengurangi pengeluaran rumah tangga untuk memenuhi kebutuhan vitamin. Ratarata warga memiliki luas lahan $500 \mathrm{~m} 2$ yang terdiri dari bangunan dan pekarangan atau lahan kosong. Pekarangan yang digunakan budidaya sekitar $80 \mathrm{~m} 2$, sehingga total pekarangan produktif untuk tanaman nanas adalah 22.960 $\mathrm{m} 2$. Dalam satu kali masa panen ( 7 bulan) biasanya dapat mencapai 11,5 ton.

Dengan jumlah angka panin seperti diatas sesungguhnya belum cukup memberi kontribusi yang positif terhadap kesejahteraan masyarakat sekitar. Problem pertama yang muncul yaitu saat buah nanas tersebut belum masuk masa panin, berarti tidak ada yang dapat dijual oleh warga sekitar. Masa panin buah nanas dapat mencapai 6 hingga 7 bulan. Problem kedua yang dirasakan oleh warga berupa tidak mencukupinya hasil penjualan buah nanas untuk mencukupi kebutuhan sehari- 
hari. Permasalahan ini telah bertahun-tahun dirasakan oleh warga. Titik terang kemudian mulai muncul saat inisiasi untuk menjalin kolaborasi dengan berbagai pihak diawali oleh Kampus Universitas Islam Raden Rahmat Malang yang telah menjadikan desa Palaan sebagai laboratorium besar dan pusat penelitian berbagai program studi yang ada di dalamnya. Pada saat yang hampir bersamaan, tepatnya pada bulan Juli tahun 2019 melalui surat nomor 115/PMD.01.05/VII/2019 desa Palaan juga memperoleh program dari Kementerian Desa Pembangunan Daerah Tertinggal dan Transmigrasi berupa PIID-PEL (Pilot Inkubasi Inovasi Desa Pengembangan Ekonomi Lokal). Program PIID-PEL ini sebagai upaya pemerintah mewujudkan pencapaian RPJMN 2015-2019 yang mentargetkan adanya pengurangan jumlah desa tertinggal sampai 5.000 desa dan meningkatkan jumlah desa mandiri sedikitnya 2.000 desa. Melalui program tersebut telah disalurkan dana sebesar Rp. 1.447.573.500. Kementerian desa melalui program ini berkeinginan untuk mendorong produktivitas serta membangun kapasitas kelembagaan ekonomi pada tingkat desa, yang melibatkan Kelompok Usaha Ekonomi Masyarakat Desa (KUEMD) termasuk koperasi dan lembaga ekonomi desa (BUMDesa) yang bermitra dengan Pelaku Bisnis Profesional (PBP) secara berkelanjutan untuk meningkatkan kesejahteraan dan kemandirian sosial ekonomi masyarakat desa. Dampak yang diharapkan dari pelaksanaan program Pilot Inkubasi Inovasi Desa-Pengembangan Ekonomi Lokal ini adalah meningkatnya omset usaha masyarakat, lapangan kerja, meningkatnya pendapatan asli desa, meningkatnya jumlah produk unggulan desa serta menguatnya peran lembaga ekonomi desa (BUMDesa).

Aktor yang dilibatkan dalam program PIID-PEL (Pilot Inkubasi Inovasi Desa Pengembangan Ekonomi Lokal) ini terdiri dari Pemerintah, swasta dan masyarakat, BUMDesa, pelaku bisnis profesional dan KUEMD (Kelompok Usaha Ekonomi Masyarakat Desa). Adapun kerangka konsep program ini adalah sebagai berikut:

Gambar 1. Kerangka Konsep Program PIID-PEL

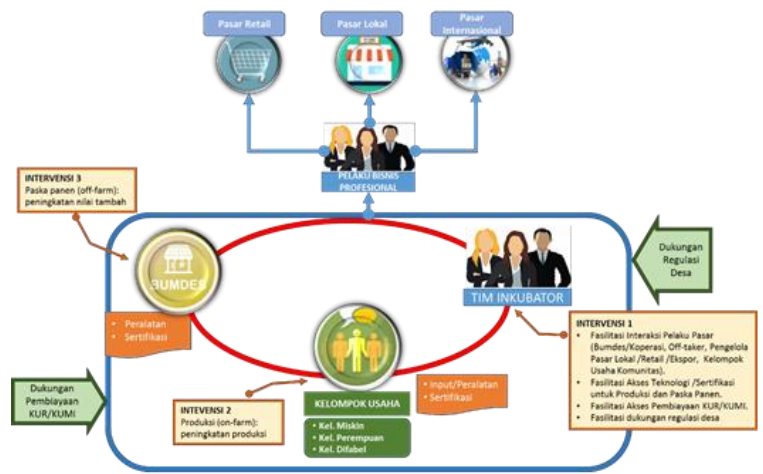

Sumber: Pedoman Umum PIID-PEL Kementerian Desa Pembangunan Daerah Tertinggal dan Transmigrasi.

Model Inovasi
Sejarah perkembangan model-model inovasi tidak bisa lepas dari keinginan manusia untuk dapat mengembangkan kesejahteraan. Model-model itu hingga kini terus mengalami perkembangan dari triple helix, quadruple helix, quintuple helix hinggapenta helix. Teoriteori inovasi banyak menekankan perihal berlangsungnya kerjasama sosial dan kegiatan ekonomi yang normal. Pusat perhatiannya pada proses inovasi non-linier yang interaktif dan dalam jaringaninovasi multi-aktor (Schienstock \& Hamalainen, 2001).

Konsep sistem inovasi dapat dibagi dalam arti sempit dan arti yang luas (Pirainen \& Koski, 2004). Sistem inovasi secara sempit dapat diartikan menggabungkan fungsi penelitian dan pengembangan universitas, institusi penelitian dan perusahaan, yang cenderung mencerminkan model inovasi top-down. Sedangkan secara luas, sistem inovasi dapat berlaku lebih interaktif dan bottom up, termasuk semua bagian dari aspek struktur ekonomi dan pengaturan institusi yang dapat memberi pengaruh pada proses belajar, pencarian dan penjelajahan (Lundvall,1992). Namun bersamaan dengan semakin menguatnya peran masyarakat atau sering pula disebut sebagai pengguna maka muncul istilah user-driven innovation yakni pengetahuan pengguna (konsumen) dimanfaatkan untuk mengembangkan produk dan jasa baru, konsep serta pemahaman berbasiskan kebutuhan pengguna, dan melibatkan para pengguna secara lebih sistematis dalam proses berlangsungnya inovasi (Wise \& Hogenhaven, 2008).

\section{Implementasi Model Quadruple Helix}

Sesuai dengan konteks penelitian di lapangan, model Quadruple Helixtentu lebih relevan bila dibanding dengan model Triple Helixkarena aktor yang berperan memang lebih dari tiga (pemerintah, industri, dan universitas). Aktor ke-empat yakni masyarakat yang sering juga disebut sebagai pengguna. Delman \& Madsen (2007) menyatakan bahwa aktor helix ke-empat yang mengarah ke struktur quadruple helix adalah organisasi independen, nonprofit dan berbasis anggota. Bahkan Yawson (2009) menyatakan bahwa inovasi muncul karena kebutuhan dari para pengguna (user-driven innovation) sehingga pengguna kemudian diformalisasikan sebagai helix ke-empat.

Sementara carayannis \& Campbell (2012) mengartikan helix ke-empat kedalam dua hal yaitu pertama budaya dan media, dan yang kedua adalah keikutsertaan masyarakat sipil dalam upaya memproduksi inovasi dan pengetahuan. Model Quadruple Helix ini meniscayakan keterlibatan masyarakat secara lebih strategis. Peran masyarakat diposisikan penting sebagai sumber inovasi. Sebagai sebuah konsep, Quadruple Helixsejatinya merupakan pengembangan dari Triple Helixdengan mengintegrasikan civil society serta mengintegrasikan inovasi dan pengetahuan (Oscar, 2010). 
Quadruple Helixmerupakan kolaborasi empat sektor sekaligus yakni governmet, business, academia (institusi sumber pengetahuan), dan civil society. Konsep ini mengakui bahwa inovasi yang dilakukan oleh warga yang kreatif dapat mendukung keberhasilan suatu tujuan bersama. Dalam Quadruple Helix, masing-masing kelembagaan bertugas memajukan inovasi dan pengembangan apapun yang dimilikinya. Sinergisitas antar seluruh aktor menjadi catatan penting bagi konsep ini. Ke-empat helix harus dapat bekerjasama agar dapat membentuk suatu keadaan yang inovatif (Rahayu, 2013).

Seluruh aktor yang ada (pemerintah, akademisi, bisnis dan masyarakat sipil) secara cerdas saling berinteraksi dengan efektif dan efisien (Carayannis \& Campbell, 2009). Masing-masing aktor dapat memainkan peran sesuai kapasitas dan kompetensinya. Pemerintah berperan dalam merumuskan suatu kebijakan, peraturan dan dukungan finansial. Sektor bisnis dan akademisi dapat berperan sebagai provider (penyedia) dan pendorong inovasi. Adapun helix ke-empat yaitu masyarakat memiliki peran yang tidak kalah strategis, mereka tidak sekedar sebagai pengguna namun juga bisa berkontribusi lebih dari itu karena konsep Quadruple Helixini membuka ide-ide segar dan brilian muncul dari sektor manapun. Uraian dibawah ini membahas peran dari setiap aktor yang ada dalam konsep Quadruple Helix dan hasil analisis terhadap kondisi empiris di desa Palaan kecamatan Ngajum kabupaten Malang.

\section{Pemerintah}

Setelah memperoleh kepastian bahwa desa Palaan akan memperoleh program PIID-PEL (Pilot Inkubasi Inovasi Desa Pengembangan Ekonomi Lokal), pemerintah desa (helix pertama) sebagai aktor penting dalam kegiatan ini segera bertindak cepat dengan menggerakkan warga desa untuk mensukseskan program tersebut. Selain itu, karena lokasi wisata berada di tanah khas desa, maka pemerintah desa segera merumuskan satu kebijakan penting berupa penggunaan tanah khas tersebut sebagai lokasi resmi kampung wisata edukasi nanas. Ini merupakan peran strategis yang telah dilakukan oleh pemerintah desa setempat.

\section{Akademisi}

Kolaborasi antar aktor menjadi krusial untuk dilakukan terlebih saat inovasi konsep desa wisata menjaditujuan. Karena program ini tidak hanya pembangunan fisik saja tetapi juga terdapat sisi penguatan kapasitas bagi stakeholder desa guna menciptakan inovasi wisata edukasi kampung nanas, maka peran akademisi juga sangat penting untuk diuraikan. Penguatan kapasitas (softskill) banyak dilakukan oleh tim inkubator (Universitas Islam Raden Rahmat Malang) sebagai konsekuensi helix kedua (akademisi) yang harus menyajikan pengetahuan aplikatif kepada para pengguna.Beberapa hal yang telah dilakukan oleh Inkubator diantaranya fasilitasi berbagai pelatihan seperti pelatihan pengelolaan destinasi wisata, pelatihan konsep wisata edukasi, pelatihan branding dan marketing desa wisata, pelatihan budidaya buah nanas, serta pelatihan kerajinan dan olahan buah nanas. Selain itu, fasilitasi interaksi dengan berbagai pelaku pasar juga dilakukan untuk keberlangsungan wisata desa ini. Menurut dokumen pedoman umum PIID-PEL 2019 yang dimaksud inkubator pada program ini adalah lembaga yang memberikan suatu program yang didesain untuk membina dan mempercepat keberhasilan pengembangan bisnis melalui rangkaian program peningkatan kapasitas untuk menjadikan usaha tersebut menjadi profitable, memiliki pengeloaan organisasi dan keuangan yang benar serta mampu menjadi lembaga usaha yang berkelanjutan, hingga akhirnya memiliki dampak positif bagi masyarakat. Berangkat dari definisi diatas, inkubator Universitas Islam Raden Rahmat Malang telah turut serta mendesain konsep wisata edukasi kampung nanas dari hulu hingga ke hilir. Sekali lagi, ini merupakan konsekuansi logis bahwa perguruan tinggi merupakan lembaga yang memproduksi pengetahuan. Ia harus hadir untuk memecahkan sekian permasalahan baik teknis maupun teoritis yang ada di masyarakat. Dua permasalahan yang sering dihadapi masyarakat desa Palaan berupa masa tunggu panin yang relatif lama dan tidak mencukupinya hasil penjualan buah nanas untuk kebutuhan sehari-hari. Dan tentu inkubator bukanlah pemain tunggal dalam pelaksanaan program ini karena terdapat aktor-aktor lain yang berperan strategis dalam perjalanan program.

\section{Bisnis (Pelaku Usaha Kreatif)}

Karena inovasi konsep wisata menjadi tujuan utama maka peran serta banyak pihak menjadi penting dibutuhkan. Memperlebar jejaring kerjasama dengan pihak eksternal menjadi satu keniscayaan. Pihak eksternal yang dipilih tentu harus dapat memberikan kontribusi pada tujuan besar yang telah terumuskan yakni membangun wisata edukasi kampung nanas. Sentuhan helix ketiga (pelaku usaha kreatif) menjadi pilihan bagi stakeholder yang telah ada untuk memberikan sumbangsih inovasi pada tujuan besar diatas. Pelaku usaha kreatif terdiri dari Industri Kecil Menengah (IKM) kabupaten Malang, KM Trans (perusahaan jasa transportasi), dan Koperta Langgeng Mulyo Group Kediri. Industri Kecil Menengah (IKM) mensupport pada ranah pengolahan buah nanas menjadi berbagai macam olahan, ide pengemasan produk hingga jejaring pemasaran. Adapun KM Trans akan berkontribusi pada pemasaran wisata edukasi kampung nanas melalui jaringan travel/transportasi yang ia miliki. Sedangkan Koperta Langgeng Mulyo Group memberikan pelatihan (hardskill)kerajinan serat daun nanas yang dapat digunakan sebagai bahan utama pembuatan tas, kursi dan jenis kerajinan tangan lainnya. Selain itu koperta 
Langgeng Utama juga akan menjadi mitra dalam pemasaran produk unggulan kerajinan serat nanas.

4. Masyarakat

Mengemas diri sebagai desa wisata tampaknya kini tengah menjadi arus utama dalam tren pembangunan desa sehingga segala potensi yang ada dan melekat pada desa menjadi semakin mungkin untuk dikembangkan dan diberikan sentuhan inovasi. Namun syarat utamanya tentu harus menghadirkan peran serta dari masyarakat desa itu sendiri. Dalam konteks desa Palaan yang telah memperoleh program diatas, masyarakat yang tergabung dalam berbagai kelompok telah memberikan kontribusinya. Setidaknya kelompok tersebut terdiri dari kelompok tani, karang taruna dan PKK. Segala potensi yang telah ada telah dimunculkan, kelompok tani misalnya, mengembangkan minuman sari buah nanas untuk menunjang branding yang nantinya akan dilekatkan pada desa Palaan sebagai kampung wisata edukasi buah nanas. Adapun peran yang dilakukan oleh karang taruna yakni mengawal komunitas muda kreatif yang ada di desa Palaan. Komunitas muda kreatif ini terjaring melalui seleksi yang diadakan oleh mereka. Tugas komunitas muda kreatif ini yaitu memberikan tanggapan atau umpan balik atas upaya penciptaan konsep inovasi desa wisata yang ada. Selain itu komunitas ini juga berperan dalam membangun budaya sadar wisata dengan sasaran masyarakat setempat. Sedangkan PKK berperan aktif dalam mensukseskan berbagai pelatihan olahan nanas yang telah diinisiasi oleh tim inkubator. Jenis pelatihan olahan nanas yang dikembangkan diantaranya pelatihan pembuatan kue nastar, moci, selai, manisan dan keripik. Semua produk tersebut menggunakan nanas sebagai bahan baku utamanya.

Setiap aktor dalam Quadruple Helix memiliki peran yang berbeda sesuai kompetensi dan kemampuannya bidangnya masing-masing. Namun sebagai konsekuensi sistem, seluruh aktor harus berkolaborasi sebagai satu kesatuan yang solid. Sinergi antar aktor yang ada dapat tercipta apabila setiap aktor dapat memainkan peranannya masing-masing tanpa bergantung pada aktor lainnya (Sofhani dan Nurrahma, 2017). Gambar dibawah ini akan menyajikan bentuk kolaborasi hingga sinergisitas antar empat aktor Quadruple Helixpada pelaksanaan program PIID-PEL (Pilot Inkubasi Inovasi Desa Pengembangan Ekonomi Lokal) di desa Palaan.

Gambar 2. Bentuk Kolaborasi Empat Aktor Quadruple Helix di Desa Palaan

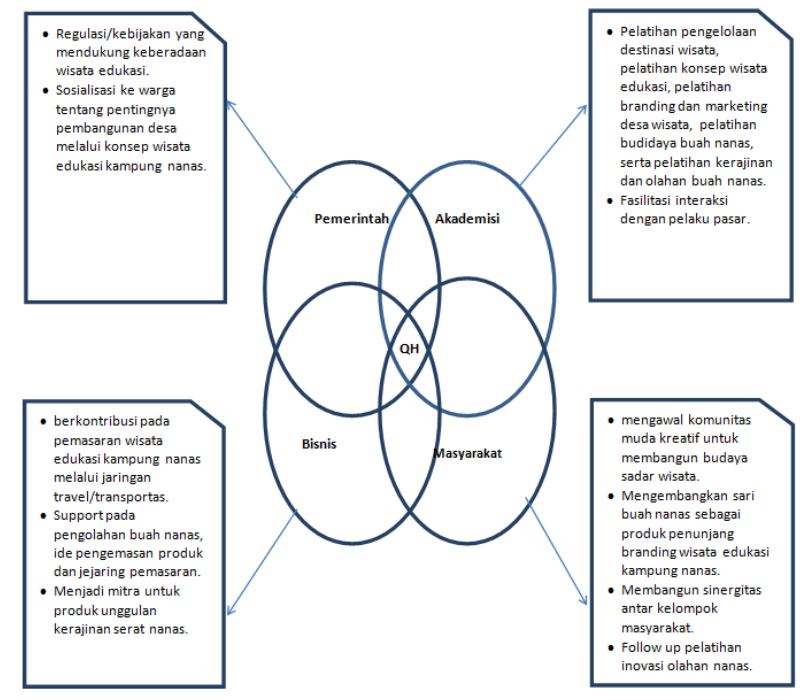

\section{Kerjasama Kolaboratif Quadruple Helix di Desa Palaan}

Penelitian ini menggambarkan bentuk kerjasama kolaboratif antar berbagai stakeholder (pemerintah, akademisi, sektor bisnis, dan masyarakat). Sejak awal bahkan sebelum program PIID-PEL (Pilot Inkubasi Inovasi Desa Pengembangan Ekonomi Lokal) ini hadir, kerjasama kolaboratif telah mulai di pupuk oleh berbagai pihak. Kesadaran akan saling membutuhkan dan saling terbuka dalam merefleksikan aspirasinya menjadi modal awal kerjasama kolaboratif ini dilakukan. Hal ini sejalan dengan yang disampaikan Robertson \& Choi (2010), bahwa tata kelola kolaboratif merupakan proses kolektif dan egalitarian dimana setiap partisipan didalamnya memiliki otoritas substantif dalam pengambilan keputusan dan setiap stakeholder memiliki kesempatan yang sama untuk merefleksikan aspirasi dalam proses tersebut. Dalam kerjasama kolaboratif terjadi penyamaan visi, tujuan, strategi dan aktivitas antara para pihak, mereka pada posisi masing-masing akan tetapi memiliki otoritas untuk mengambil keputusan secara independen dan memiliki otoritas dalam mengelola organisasinya meskipun mereka tunduk pada kesepakatan bersama (Dwiyanto, 2011). Intinya bahwa setiap entitas yang tergabung dalam kolaborasi pasti memiliki kepentingan yang akan dibawa dalam sebuah keputusan dan masingmasing akan menawarkan solusi alternatif dari suatu problem yang dihadapi, namun didalamnya tetap menjunjung asas kesepakatan bersama. Kerjasama antar empat aktor di desa Palaan ini diinisiasi atas keterbatasan kapasitas, sumberdaya ataupun jaringan yang dimiliki oleh masing-masing stakeholder (Subarsono, 2016). Pada gilirannya, kerjasama tersebut dapat menyatukan komponen yang mendorong keberhasilantarget dan tujuan bersama.

Terdapat lima karakteristik yang terus selalu dibangun oleh setiap aktor helix yang ada di desa Palaan untuk menjaga ritme kerjasama kolaboratif tersebut, diantaranya: 
1. Setiap forum urun rembuk dapat diinisiasi oleh siapapun dan tidak harus diinisiasi oleh pemerintah misalnya atau bahkan akademisi.

2. Peserta dapat terlibat secara langsung dalam perumusan keputusan dan tidak harus terpaku pada aktor-aktor publik.

3. Peserta di dalam forum juga termasuk aktor non publik, artinya bahwa seluruh ke-empat aktor memiliki peran yang setara karena ide dapat muncul dari aktor manapun.

4. Forum diadakan secara bersama-sama dan bermuara pada konsensus.

5. Kolaborasi antar stakeholder tersebut berfokus pada pengambilan keputusan yang paling ideal bagi keberhasilan program (cita-cita bersama).

Dari lima karakteristik diatas, muncullah ide inovasi konsep yang akan dikembangkan untuk mewujudkan wisata edukasi kampung nanas di desa Palaan. Inovasi konsep ini lahir atas beragam masalah ekonomi yang dihadapi oleh warga desa khususnya yang telah menanam buah nanas. Dengan adanya wisata edukasi kampung nanas, diharapkan tidak lagi ada keluhan dari warga terkait lamanya masa menunggu panin dan lain sebagainya. Hal ini karena di dalam konsep wisata edukasi kampung nanas bakal terdapat banyak potensi yang akan digali dan banyak pula peluang kerja yang akan tercipta bagi warga desa Palaan.

Tabel 1. Bentuk Inovasi, Peluang Kerja dan sasaran Program

\begin{tabular}{|c|c|c|}
\hline Bentuk Inovasi & Peluang Kerja & Sasaran \\
\hline $\begin{array}{l}\text { Beragam olahan } \\
\text { dari buah nanas } \\
\text { (sari buah, moci, } \\
\text { kue nastar, selai, } \\
\text { keripik, } \\
\text { kerajinan serat } \\
\text { daun nanas) }\end{array}$ & $\begin{array}{l}\text { Memberikan } \\
\text { peluang bagi ibu } \\
\text { rumah tangga } \\
\text { yang kebanyakan } \\
\text { tidak memiliki } \\
\text { pekerjaan. }\end{array}$ & $\begin{array}{l}\text { Ibu rumah } \\
\text { tangga, PKK, } \\
\text { kelompok tani } \\
\text { dan } \\
\text { pengangguran. }\end{array}$ \\
\hline $\begin{array}{l}2 \text { lokasi wisata } \\
\text { yang terintegrasi } \\
\text { (Cafe nanas dan } \\
\text { museum nanas) }\end{array}$ & $\begin{array}{l}\text { Memberikan } \\
\text { peluang untuk } \\
\text { bekerja di cafe, } \\
\text { merawat lokasi } \\
\text { wisata dan } \\
\text { museum nanas. }\end{array}$ & $\begin{array}{l}\text { kelompok karang } \\
\text { taruna }\end{array}$ \\
\hline $\begin{array}{l}\text { Paket wisata } \\
\text { cooking class } \\
\text { dan farming } \\
\text { classdengan } \\
\text { sasaran pasar } \\
\text { anak usia dini } \\
\text { dan tingkat } \\
\text { sekolah dasar. }\end{array}$ & $\begin{array}{l}\text { Memberikan } \\
\text { peluang bagi } \\
\text { warga yang } \\
\text { rumahnya berada } \\
\text { disepanjang jalan } \\
\text { yang dilalui } \\
\text { kereta nanas. }\end{array}$ & $\begin{array}{l}\text { Ibu rumah } \\
\text { tangga, PKK dan } \\
\text { kelompok tani }\end{array}$ \\
\hline $\begin{array}{l}\text { Wisata agro } \\
\text { (tour kampung } \\
\text { nanas dan petik }\end{array}$ & $\begin{array}{l}\text { Membuka } \\
\text { peluang menjadi } \\
\text { tour guide }\end{array}$ & Karangtaruna \\
\hline
\end{tabular}

Inovasi konsep diatas lahir dari hasil kerjasama kolaboratif seluruh helix yang ada. Melalui lima karakteristik yang dibangun diatas nyatanya cukup mampu membuahkan hasil inovasi konsep yang cukup membanggakan bagi semua pihak meski pada tahap realisasi beberapa masih akan diuji. Namun, konsistensi yang ditunjukkan pada diri setiap aktor tampaknya memberikan rasa optimisme tinggi bagi khalayak. Yang tidak boleh dilupakan bagi para pengelola desa wisata dimanapun adalah tidak berhentinya kreatifitas. Kreatifitas merupakan unsur penting dalam pengembangan kinerja inovasi (Setyanti dan Wahyuni, 2019). Upaya meningkatkan kreatifitas dapat muncul dari helix manapun agar keunggulan bersaing selalu dapat dijaga. Hal ini karena pada setiap kreatifitas yang dilahirkan akan tercipta produk unggulan dan jasa baru yang sulit untuk ditiru oleh para pesaing. Untuk itu, analisis terhadap perubahan dan situasi pasar, konsumen serta perkembangan teknologi harus terus dilakukan secara komprehensif.

Upaya mendorong kreatifitas untuk melahirkan inovasi baru perlu terus dilakukan agar bisa tetap bertahan ditengah industri wisata yang semakin beragam. Kreatifitas perlu didorong untuk memunculkan ide-ide baru yang menumbuhkan produk dan jasa yang mampu bersaing dengan kualitas yang dimiliki serta tetap baik dihati konsumen. Agar kreatifitas dan inovasi memberikan hasil yang maksimal maka kolaborasi Quadruple Helix sangat diperlukan sehingga perbaikan secara terus-menerus dapat selalu ditingkatkan.

Wisata edukasi kampung nanas akan menjadi pusat kolaborasi dan pemberdayaan masyarakat berbasis 
potensi yang dimiliki oleh desa. Didalamnya akan muncul berbagai inovasi yang didukung oleh interaksi empat helix yaitu pemerintah, akademisi, bisnis dan masyarakat. Suasana berbagi pengetahuan harus terus ditingkatkan demi semakin terciptanya berbagai kreatifitas. Kolaborasi Quadruple Helix telah mampu menghasilkan inovasi konsep wisata edukasi kampung nanas, ini menjadi bukti bahwa praktek kolaborasi menjadi kunci utama dalam mengembangkan potensi yang dimiliki oleh desa. Ke-empat helix diatas merupakan faktor determinan penggagas munculnya ide, kreatifitas, ilmu pengetahuan, kesadaran berbagi, dan teknologi bagi berkembangnya desa wisata.

\section{PENUTUP}

\section{Simpulan}

Di desa Palaan, model Quadruple Helixini nyatanya mampu melahirkan ide dan kreatifitas hingga pengetahuan baru melalui dukungan seluruh aktor (pemerintah, akademisi, bisnis atau pelaku usaha kreatif, dan masyarakat). Dukungan dari seluruh helix yang ada dibutuhkan untuk terus mendorong hadirnya kreatifitas dari sektor manapun. Masyarakat tidak boleh hanya menjadi pengguna ide dan kreatifitas dari helix lainnya, mereka juga dapat menunjukkan bahwa kreatifitas dan inovasi juga dapat muncul dari masyarakat. Saat kreatifitas dan inovasi dapat selalu dihadirkan, maka setiap produk akan memiliki nilai tambah yang unggul dan berdaya saing. Untuk itu, sinergi yang baik dari seluruh elemen Quadruple Helixmenjadi syarat utama hadirnya kreatifitas dan inovasi..

\section{Saran}

Penelitian ini sekaligus memberikan saran bagi interaksi yang terbangun antara pemerintah, akademisi, bisnis dan masyarakat. Interaksi yang ideal, sehat, setara dan saling berbagi pengetahuan menjadi penting untuk diperhatikan setiap helix yang ada. Selain itu, penelitian tahap selanjutnya menjadi penting dilakukan saat wisata edukasi kampung nanas nantinya sudah mulai berjalan, hal ini dikarenakan, dinamika dilapangan pasti terus bergeser seperti perlunya aktor tambahan dalam proses pengembangan wisata tersebut.

\section{DAFTAR PUSTAKA}

Carayannis, E. G., and Campbell, D. F. J. (2009). Mode 3 and Quadruple Helix: toward a 21st century fractal innovation ecosystem. International journal of Technology Management, 46 (3), 201-234.

Delman, J., \& Madsen, ST. (2007), Nordic Triple Helix Collaboration in Knowledge, Innovation, and business in China and India: a Preliminary Study. NIAS-Nordic Institute of Asian Studies, Copenhagen.
Dwiyanto, Agus. 2011. Manajemen Pelayanan Publik: Peduli, Inklusif, dan Kolaboratif. Yogyakarta: Gadjahmada University Press. hal. 251.

Kumorotomo, Wahyudi dkk 2013. Transformasi pelayanan Jakarta Commuter Line: Studi Tentang Collaborative Governance di Sektor Publik. Fisipol, UGM. Halaman 10.

Lundvall, B. -A. (Ed.). (1992), National Systems of innovation. Toward a Theory of Innovation and Interactive Learning. London: Pinter Publishers.

Oscar. A, Monterino, S., \& Thomson, M. (2010). A growth model for the quadruple helix innovation theory. Journal of Business Economics \& Management.

Rahayu, Sri. (2013), “The Quadruple Helix Model (Universities, Academic, Entreprises, Government and Community) Sebagai Model Ideal Untuk Sistem Inovasi Lokal Efektif Terkait Penanggulangan Kemiskinan Di Negara Bekembang", Pusat Penelitian Perkembangan Iptek-LIPI, 2013.

Schienstock, G. \& Hamalainen, T. (2001), Transformation of the Finish Innovation System: A Network Approach. Sitra Reports series 7. Helsinki: Sitra.

Subarsono, Agustinus. 2016. Kebijakan Publik dan Pemerintahan Kolaboratif Isu-Isu Kontemporer. Yogyakarta: Penerbit Gava Media. Hal. 177.

Wise, E. \& Hogenhaven, T. (2008), User-Driven Innovation. Contex and Cases in the Nordic Region. Nordic Innovation Centre.

Yawson, R. M. (2009), The Ecological Systems of Innovation: A New Architectural Framework for a Fungtional Evidence-Based Platform for Science and Innovation Policy, The Future of Innovation, Proceedings of the XXIV ISPIM 2009 Conference, Vienna, Austria, June 21-24, 2009.

Dokumen Pedoman Umum PIID-PEL Kementerian Desa Pembangunan Daerah Tertinggal dan Transmigrasi. 